\title{
Role of the Phosphatidylinositol 3-Kinase/Protein Kinase B Pathway in Regulating Alternative Splicing of Tissue Factor mRNA in Human Endothelial Cells
}

\author{
Andreas Eisenreich, MSc; Ronny Malz, MSc; Wojciech Pepke; Yunus Ayral; \\ Wolfgang Poller, MD; Heinz-Peter Schultheiss, MD; Ursula Rauch, MD
}

\begin{abstract}
Background: Tissue factor (TF) is the primary initiator of blood coagulation. In response to tumor necrosis factor (TNF)- $\alpha$ human umbilical vein endothelial cells (HUVECs) express 2 TF isoforms: a soluble alternatively spliced isoform (asHTF) and membrane-bound "full length" (fl)TF. How the differential TF isoform expression is regulated is still unknown. This study compared the impact of PI3K/Akt pathway inhibition on alternative splicing of TF in HUVECs, to the influence of transcriptional regulation by inhibiting nuclear factor $\kappa \mathrm{B}(\mathrm{NF} \kappa \mathrm{B})$.

Methods and Results: The mRNA expression of TF isoforms was assessed by real-time PCR, the thrombogenic activity was measured by a chromogenic TF activity assay and the phosphorylation state of serine/arginine-rich (SR) proteins was analyzed by western blotting. Transfection of HUVECs was done $72 \mathrm{~h}$ before the inhibition experiments were performed. PI3K/Akt pathway inhibition reduced the mRNA expression of asHTF but not flTF. Inhibition of $\mathrm{NF}_{\kappa} \mathrm{B}$ reduced the expression of both isoforms. Moreover, the PI3K/Akt pathway inhibition, but not that of $\mathrm{NF}_{\kappa} \mathrm{B}$, modified the phosphorylation of the SR proteins SRp75, SRp55 and SF2/ASF. Additionally, overexpression of SF2/ASF and SRp75 influenced the differential TF-isoform expression in HUVECs.

Conclusions: The PI3K/Akt pathway modulates alternative splicing of TF in HUVECs, distinct from transcriptional regulation. (Circ J 2009; 73: 1746-1752)
\end{abstract}

Key Words: Cytokines; Endothelial function; Inflammation; Kinase; Thrombosis

$\mathbf{T}$ issue factor (TF) is a $47-\mathrm{kD}$ transmembrane cellsurface glycoprotein and the primary initiator of the blood coagulation cascade. ${ }^{1-4}$ Endothelial cells are crucial regulators of vascular wall homeostasis and blood thrombogenicity; ${ }^{5-7}$ the inflammatory cytokine tumor necrosis factor (TNF)- $\alpha$ has been shown to induce the expression of 2 TF isoforms: membrane-bound human "full length" TF (flTF), ${ }^{8-10}$ and a soluble alternatively spliced human TF (asHTF). $6,10,11$ Both TF isoforms circulate in blood.6,12

Fully active flTF appears to be the major source of the thrombogenicity of blood in a cancer setting. ${ }^{13}$ The function of asHTF is as yet unknown. It has been suggested that asHTF participates in thrombogenesis in vivo, although it is much less procoagulant than flTF in conventional static assays. ${ }^{6,12,14}$ Alternatively asHTF may be linked to increased cell proliferation and angiogenesis. ${ }^{15}$

Alternative splicing of pre-messenger RNA (pre-mRNA) is an important eukaryotic mechanism for regulating gene expression, protein diversity and functional variability. ${ }^{14,16}$ Serine/arginine-rich (SR) proteins are a family of highly conserved factors crucial for constitutive and alternative splicing of pre-mRNA. ${ }^{16-18}$ Several SR protein kinases have been reported to phosphorylate SR proteins, thereby regulating the activity of SR proteins in alternative splicing processes. ${ }^{17-21}$ Protein kinase B (Akt) is one of these SR protein kinases. ${ }^{18,22}$ The phosphatidylinositol 3-kinase (PI3K)/Akt pathway affects SR protein phosphorylation and alternative splicing processes..$^{23,24}$

It is unknown whether SR protein kinases are involved in regulated TF pre-mRNA splicing in endothelial cells. Thus, the present study assessed the impact of the PI3K/Akt pathway on regulating TNF- $\alpha$-induced TF isoform expression and phosphorylation state of SR proteins in human umbilical vein endothelial cells (HUVECs).

\section{Methods}

\section{Cell Culture}

Pooled HUVECs were cultured in EC growth medium (containing $5 \%$ fetal calf serum) at $37^{\circ} \mathrm{C}$ in a humidified incubator $\left(5 \% \mathrm{CO}_{2}, 95 \%\right.$ air). Cells from passages 2-6 were used. For inhibition experiments, HUVECs were switched to EC basal medium (without fetal calf serum) for $1 \mathrm{~h}$ and then pre-treated with $1,2.5$ and $5 \mu \mathrm{mol} / \mathrm{L}$ of the PI3K/Akt pathway inhibitor LY294002 (Calbiochem, Darmstadt, Germany) or $10 \mu \mathrm{mol} / \mathrm{L}$ of the $\mathrm{NF} \kappa \mathrm{B}$ inhibitor BAY 117082 (Calbiochem) for another $1 \mathrm{~h}$. Next, the cells were stimulated with $10 \mathrm{ng} / \mathrm{ml}$ TNF- $\alpha$ for $1 \mathrm{~h}$ for mRNA analysis or for $5 \mathrm{~min}$ for the assessment of the phosphorylation state of SR proteins. Positive controls were stimulated with TNF- $\alpha$ only and negative controls were not treated.

(Received April 1, 2009; revised manuscript received April 22, 2009; accepted April 23, 2009; released online July 13, 2009)

Charitè-Universitätsmedizin Berlin, Campus Benjamin Franklin, Centrum für Herz- und Kreislaufmedizin, Berlin, Germany

Mailing address: Andreas Eisenreich, MSc, Charitè-Universitätsmedizin Berlin, Campus Benjamin Franklin, Centrum für Herz- und Kreislaufmedizin, Berlin, Germany. E-mail: andreas.eisenreich@charite.de

All rights are reserved to the Japanese Circulation Society. For permissions, please e-mail: cj@j-circ.or.jp 
A

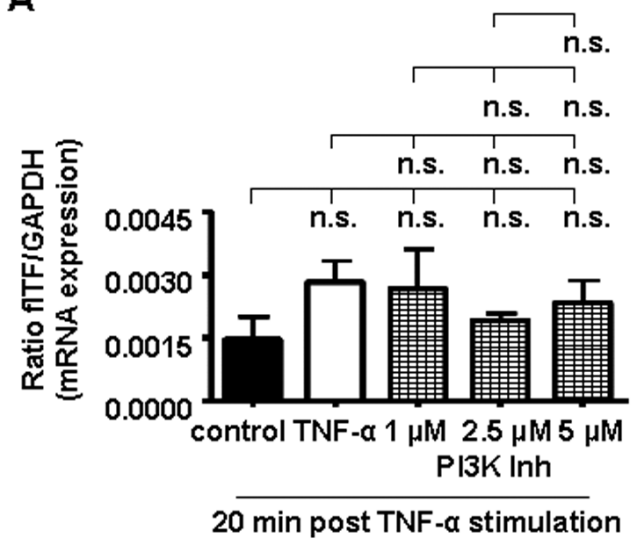

C

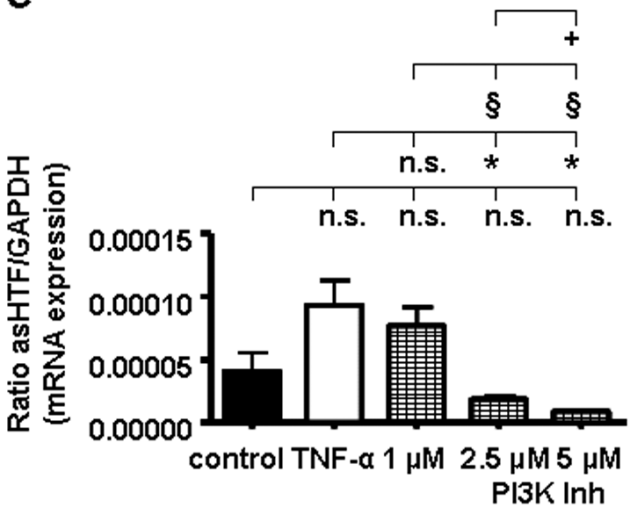

20 min post TNF- $\alpha$ stimulation

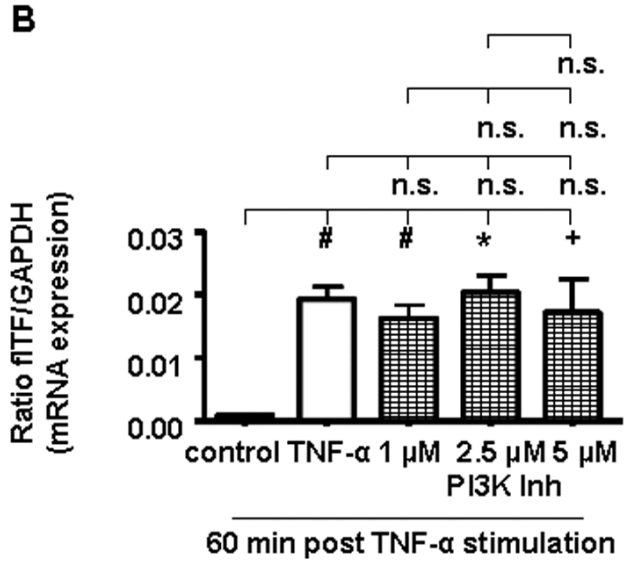

D

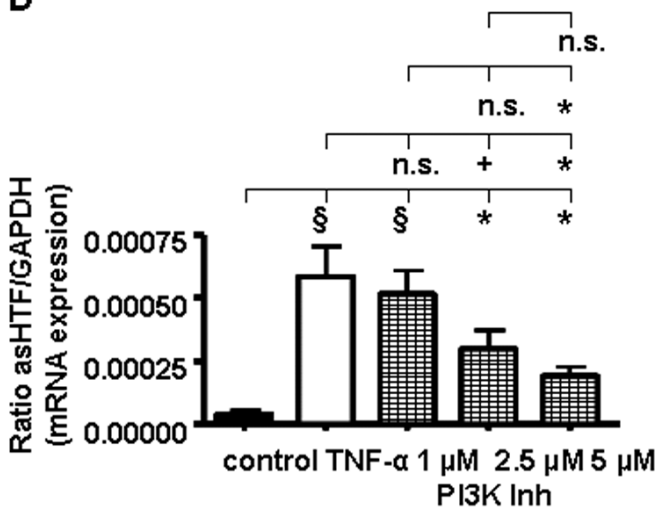

$60 \overline{\text { min post TNF- } \alpha \text { stimulation }}$

Figure 1. Inhibition of the PI3K/Akt pathway alters the differential TF mRNA expression. $(\mathbf{A}, \mathbf{B})$ Ratio of the flTF mRNA expression normalized against GAPDH of $5 \times 10^{5}$ HUVECs, $20 \mathrm{~min}(\mathbf{A})$ or $60 \mathrm{~min}(\mathbf{B})$ post TNF- $\alpha$ stimulation. (C,D) Ratio of the alternatively spliced human TF (asHTF) mRNA expression normalized against GAPDH $20 \mathrm{~min}(\mathbf{C})$ and $60 \mathrm{~min}(\mathrm{D})$ post TNF- $\alpha$ induction. Shown are non-stimulated cells (control), TNF- $\alpha$-stimulated HUVECs (TNF- $\alpha$ ) and cells treated with $1,2.5$ or $5 \mu \mathrm{mol} / \mathrm{L}$ of the PI3K Inh. In $\mathbf{A}-\mathbf{D}$ the mean \pm SEM of at least 5 independent experiments is shown. ${ }^{+} \mathrm{P}<0.05 ; * \mathrm{P}<0.01 ;{ }^{\circledR} \mathrm{P}<0.001 ;{ }^{\#} \mathrm{P}<0.0001$ compared with unstimulated controls or TNF- $\alpha$-treated cells. asHTF, alternatively spliced human tissue factor (TF); flTF, full-length TF; HUVEC, human umbilical vein endothelial cell; PI3K Inh, PI3K/Akt pathway inhibitor; NS, no significant difference; TNF, tumor necrosis factor.

\section{TF Isoform-Specific Real-Time PCR (TaqMan)}

Real-time PCR using fITF, asHTF, and GAPDH-specific primers and probes was performed as previously described. 25,26

Overexpression of SF2/ASF and SRp75 The $1 \times 10^{5}$ HUVECs were transfected with $3 \mu \mathrm{g}$ of the expression plasmid pCMV6-Entry-SFRS4 or SFRS1 (OriGene Technologies Inc, Rockville, MD, USA) coding for SRp75 or SF2/ASF, respectively. Transfection was performed with a HUVECs Nucleofector ${ }^{\circledR}$ Kit (Amaxa Biosystems, Cologne, Germany). The overexpression of both SR proteins was monitored by determining mRNA levels after $48 \mathrm{~h}$ upon transfection. At $72 \mathrm{~h}$ post transfection, cells were stimulated with TNF- $\alpha$ for $1 \mathrm{~h}$, total RNA collected, reverse transcribed, and subjected to real-time PCR analysis.

Determination of TF Activity Measurement of thrombogenicity of stimulated and non-stimulated HUVECs, as well as cells pre-treated with inhibitors, was performed as previously described. ${ }^{6}$

\section{Western Blot}

Western blot analysis of samples from cell lysates of inhib- ited, stimulated and unstimulated HUVECs was performed as previously described.25 For detection of phosphorylated SR proteins monoclonal antibody mAb1H4 (Invitrogen $\mathrm{GmbH}$, Karlsruhe, Germany) was used. Phosphorylationindependent detection of SRp75, SRp55, and SF2/ASF was done via the monoclonal antibodies $\mathrm{mAb} 16 \mathrm{H} 3$ and $\mathrm{mAb} 103$ (Invitrogen $\mathrm{GmbH}$ ).

Quantification of Western Blots The results of western blot experiments were quantified using Gel-Pro Analyzer ${ }^{\mathrm{TM}}$ software version 4.0.00.001 (Media Cybernetics, Bethesda, MD, USA).

\section{Statistical Analysis}

All data are expressed as mean \pm SEM. Data were analyzed by Student's t-test or 1-way ANOVA as appropriate. A probability value $\leq 0.05$ was regarded as significant.

\section{Results}

Inhibition of the PI3K/Akt Pathway Modulates Alternative Splicing of TF Pre-mRNA

Unstimulated HUVECs do not constitutively express TF. ${ }^{6}$ 
A

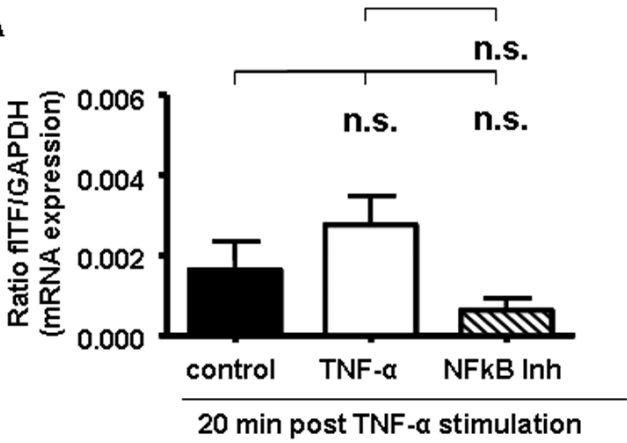

C
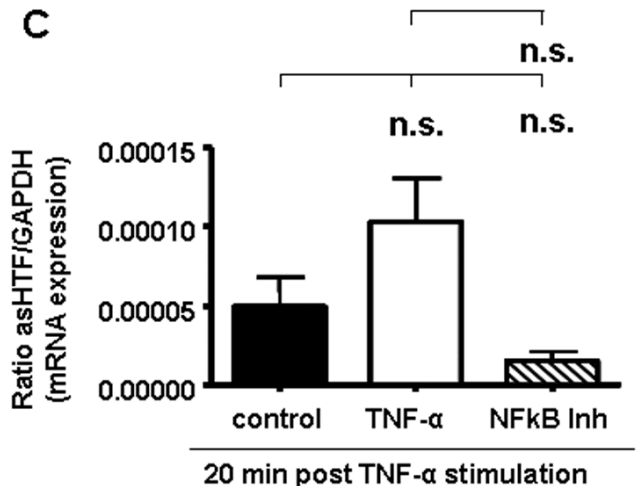

B
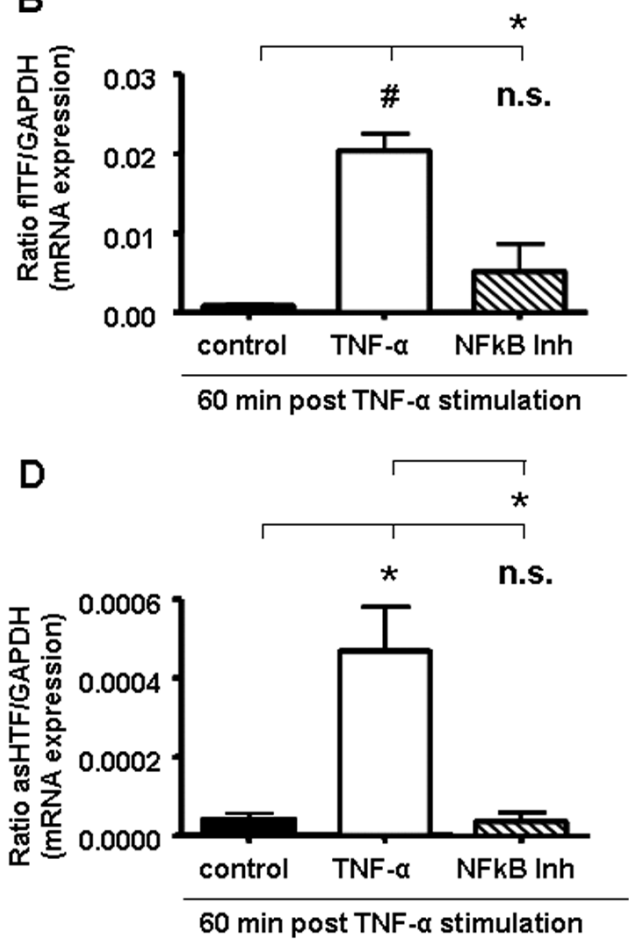

Figure 2. Inhibition of $\mathrm{NF} \kappa \mathrm{B}$ reduces the mRNA expression of both $\mathrm{TF}$ isoforms. (A,B) Ratio of the flTF mRNA expression normalized against GAPDH of $5 \times 10^{5} \mathrm{HUVEC}, 20 \mathrm{~min}(\mathbf{A})$ or $60 \mathrm{~min}(\mathbf{B})$ post TNF- $\alpha$ stimulation. (C,D) Ratio of the asHTF mRNA expression normalized against GAPDH $20 \mathrm{~min}(\mathbf{C})$ and $60 \mathrm{~min}(\mathbf{D})$ post TNF- $\alpha$ induction. Shown are non-stimulated cells (control), TNF- $\alpha$-stimulated HUVEC (TNF- $\alpha$ ) and cells treated with $10 \mu \mathrm{mol} / \mathrm{L}$ of the NF $\kappa \mathrm{B}$ inhibitor $\left(\mathrm{NF} \kappa \mathrm{B}\right.$ Inh). In $\mathbf{A}-\mathbf{D}$ the mean $\pm \mathrm{SEM}$ of at least 4 independent experiments is shown. $+\mathrm{P}<0.05 ; * \mathrm{P}<0.01$; ${ }^{*} \mathrm{P}<$ 0.0001 compared to unstimulated controls or TNF- $\alpha$-treated cells. NF $\kappa \mathrm{B}$, nuclear factor $\kappa \mathrm{B}$. See Figure 1 and text for other abbreviations.

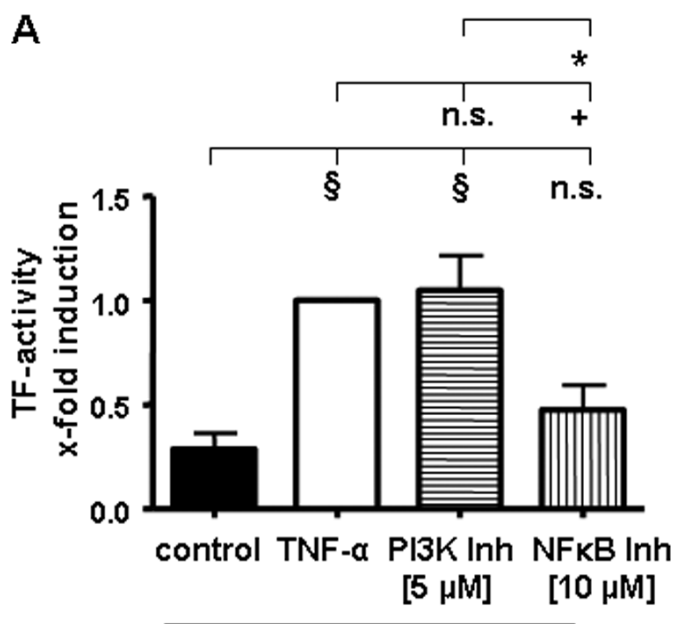

$5 \mathrm{~h}$ post TNF- $\alpha$ stimulation

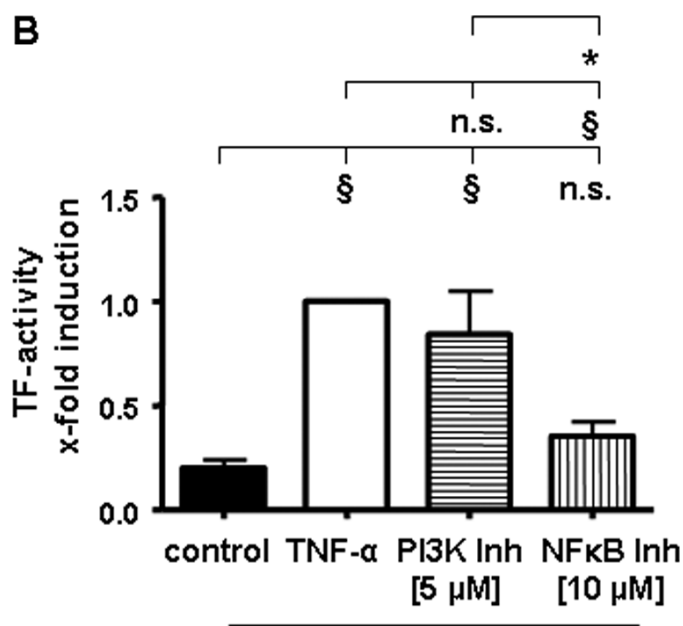

$24 \mathrm{~h}$ post TNF- $\alpha$ stimulation

Figure 3. Impact of the PI3K/Akt pathway and $\mathrm{NF} \kappa \mathrm{B}$ on the TF activity. TF activity, $5 \mathrm{~h}(\mathrm{~A})$ and $24 \mathrm{~h}(\mathbf{B})$ post TNF- $\alpha$ stimulation. Shown are unstimulated cells (control), TNF- $\alpha$-stimulated HUVECs (TNF- $\alpha$ ), cells treated with $5 \mu \mathrm{mol} / \mathrm{L}$ of the PI3K Inh and cells treated with $10 \mu \mathrm{mol} / \mathrm{L}$ of the $\mathrm{NF} \kappa \mathrm{B}$ Inh. The data are displayed as $\mathrm{x}$-fold induction of TF activity per $1 \times 10^{6}$ cells. The mean \pm SEM of at least 9 independent experiments is shown. ${ }^{+} \mathrm{P}<0.05 ; * \mathrm{P}<0.01 ;{ }^{\circledR} \mathrm{P}<0.001$ compared to nontreated controls or TNF- $\alpha$-stimulated cells. $\mathrm{NF} \kappa \mathrm{B}$ Inh, $\mathrm{NF} \kappa \mathrm{B}$ inhibitor. See Figures 1,2 and text for other abbreviations.

Stimulation of HUVECs with TNF- $\alpha$ tended to result in increased mRNA expression of asHTF, but not flTF $20 \mathrm{~min}$ post stimulation (Figures 1A,C). The mRNA expression of both TF isoforms was significantly increased $60 \mathrm{~min}$ post TNF- $\alpha$ stimulation (Figures 1B,D). Inhibition of the PI3K/
Akt pathway by doses of $1-5 \mu \mathrm{mol} / \mathrm{L}$ of the specific inhibitor LY294002 27 had no significant effect on the TNF- $\alpha$-induced increase in flTF mRNA at 20 as well as $60 \mathrm{~min}$ post TNF- $\alpha$ stimulation (Figures 1A, B). In contrast to the flTF mRNA expression, the asHTF level was significantly reduced in 
A

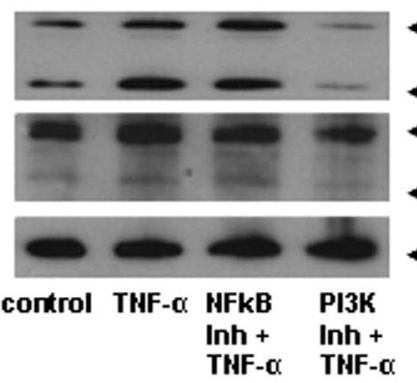

5 min post THF- $\alpha$ (phosphorylationdependent antbodies)

B
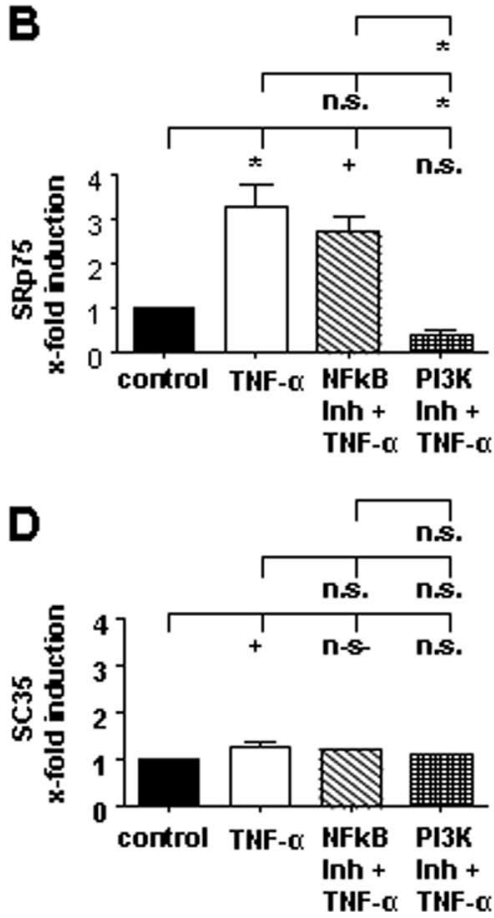
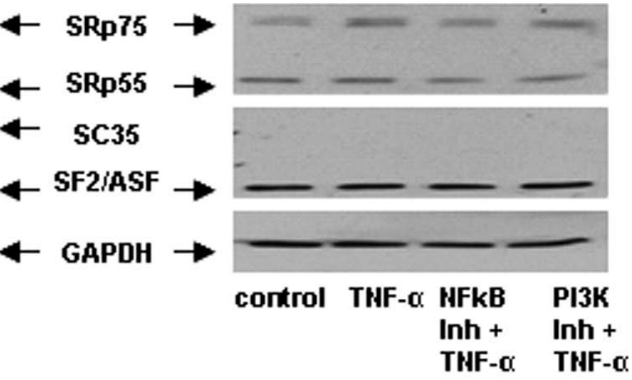

5 min post THF- $\alpha$ (phosphorylationindependent antibodies)

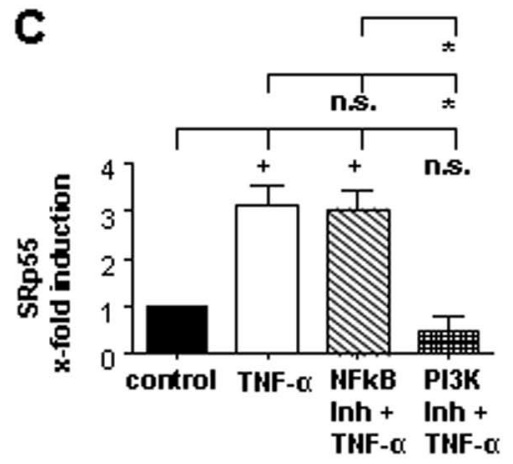

E

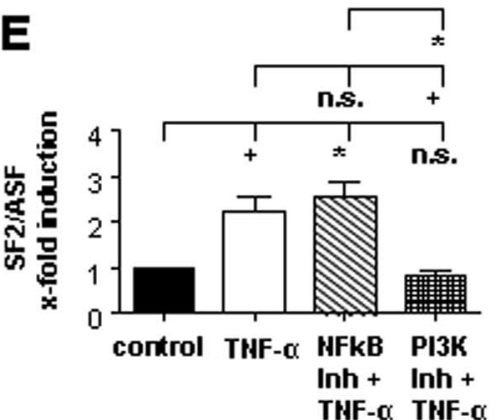

Figure 4. Inhibition of the PI3K/Akt pathway, but not $\mathrm{NF} \kappa \mathrm{B}$, alters the phosphorylation state of SRp75, SRp55 and SF2/ASF. Western blot analyses showing the phosphorylation state of the SR proteins SRp75, SRp55, SC35 and SF2/ASF in HUVEC (A, Left) and the expression of whole SRp75, SRp55 and SF2/ASF (A, Right), $5 \mathrm{~min}$ post TNF- $\alpha$ stimulation. Displayed are unstimulated cells (control), TNF- $\alpha$-induced HUVECs $(\mathrm{TNF}-\alpha)$ and cells treated with PI3K Inh and $\mathrm{NF} \kappa \mathrm{B}$ Inh. At least 3 independent experiments were performed. (B-E) Western blot quantification. Shown is the $\mathrm{x}$-fold induction of the band density as mean \pm SEM. $+\mathrm{P}<0.05$; $* \mathrm{P}<0.01$ compared to non-treated controls or TNF- $\alpha$-stimulated cells. SR, serine/argininerich. See Figures 1-3 and text for other abbreviations. a concentration-dependent manner by the pre-treatment of cells with $1-5 \mu \mathrm{mol} / \mathrm{L}$ of the PI3K/Akt pathway inhibitor before stimulation with $\mathrm{TNF}-\alpha$ for 20 as well as $60 \mathrm{~min}$ (Figures 1C,D).

In contrast to inhibition of the PI3K/Akt pathway, inhibition of $\mathrm{NF}_{\kappa} \mathrm{B}$ by $10 \mu \mathrm{mol} / \mathrm{L}$ BAY $11-7082$ reduced the TNF- $\alpha$-induced mRNA expression of both TF isoforms (Figures 2A-D).

Impact of $\mathrm{NF} \kappa \mathrm{B}$ Inhibition and Inhibition of the PI3K/ Akt Pathway on Thrombogenic Activity of TNF- $\alpha$ -

\section{Stimulated HUVECs}

$\mathrm{NF} \kappa \mathrm{B}$ is known to play a role in progressing the inflammatory response in atheroslerosis. ${ }^{28}$ To determine the impact of $\mathrm{NF} \kappa \mathrm{B}$ inhibition or inhibition of the PI3K/Akt pathway on endothelial thrombogenicity, a chromogenic TF activity assay based on generation of factor $\mathrm{Xa}$ by $\mathrm{TF}$, was performed (Figure 3). Stimulation of cells with TNF- $\alpha$ led to a significantly increased TF activity at 5 and $24 \mathrm{~h}$ post stimulation compared with non-stimulated controls. Inhibition of the PI3K/Akt pathway with $5 \mu \mathrm{mol} / \mathrm{L}$ of LY294002 had no effect on the TNF- $\alpha$-induced increase in TF activity. In contrast to inhibition of the PI3K/Akt pathway, inhibition of $\mathrm{NF} \kappa \mathrm{B}$ reduced the $\mathrm{TF}$ activity to baseline level at $5 \mathrm{~h}$ as well as $24 \mathrm{~h}$ post stimulation with TNF- $\alpha$.

Inhibition of PI3K/Akt Pathway but Not NF $\kappa$ B Altered the Phosphorylation Pattern of SR Proteins

Western blots with antibodies against phosphorylated SR proteins were performed to assess the phosphorylation state of SR proteins $5 \mathrm{~min}$ post TNF- $\alpha$-stimulation. The SR protein family members, SRp75, SRp55, SC35 and SF2/ASF, were detected in HUVECs (Figure 4A, Left). We found TNF- $\alpha$ to increase the phosphorylation of these SR proteins (Figures 4B-E). Treatment of HUVECs with the $5 \mu \mathrm{mol} / \mathrm{L}$ of the PI3K/Akt pathway inhibitor reduced the phosphorylation state of SRp75, SRp55 and SF2/ASF. In contrast, the inhibition of $\mathrm{NF} \kappa \mathrm{B}$ had no effect on the TNF- $\alpha$-induced increase in SR protein phosphorylation. By determining the expression of whole SRp75, SRp55 and SF2/ASF via phosphorylation-independent antibodies, we demonstrated that inhibition of neither the PI3K/Akt pathway nor $\mathrm{NF}_{\kappa} \mathrm{B}$ affected the protein expression level $5 \mathrm{~min}$ post $\mathrm{TNF}-\alpha$ stimulation (Figure 4A, Right).

\section{Overexpression of SRp75 Influences Differential TF mRNA Expression}

The phosphorylation state of SR proteins regulates their 
A

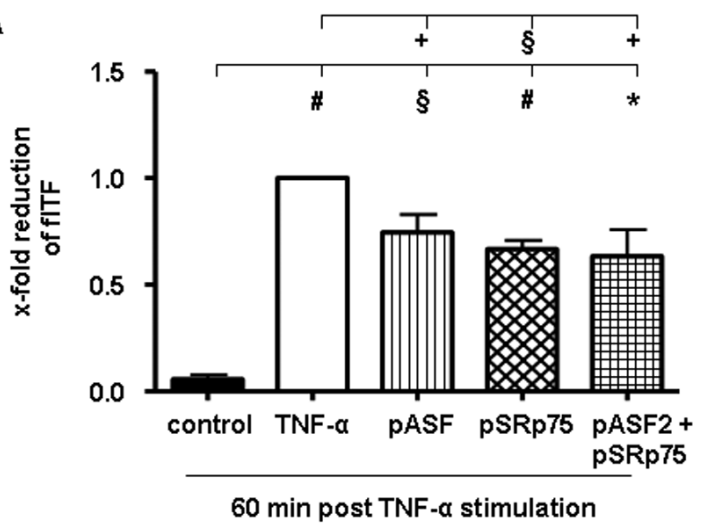

C

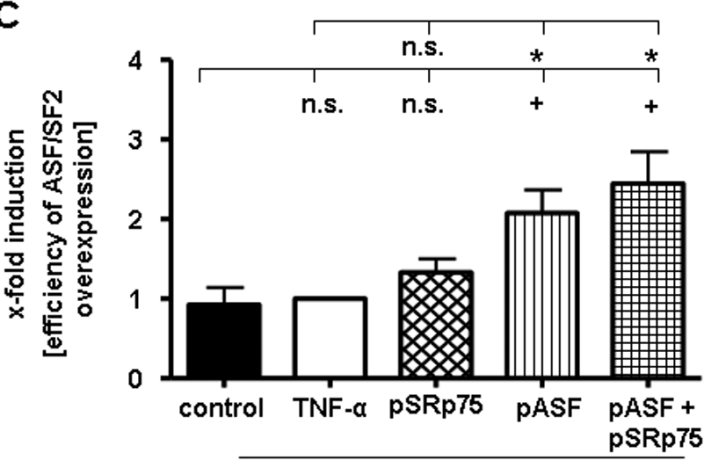

$48 \mathrm{~h}$ post transfection
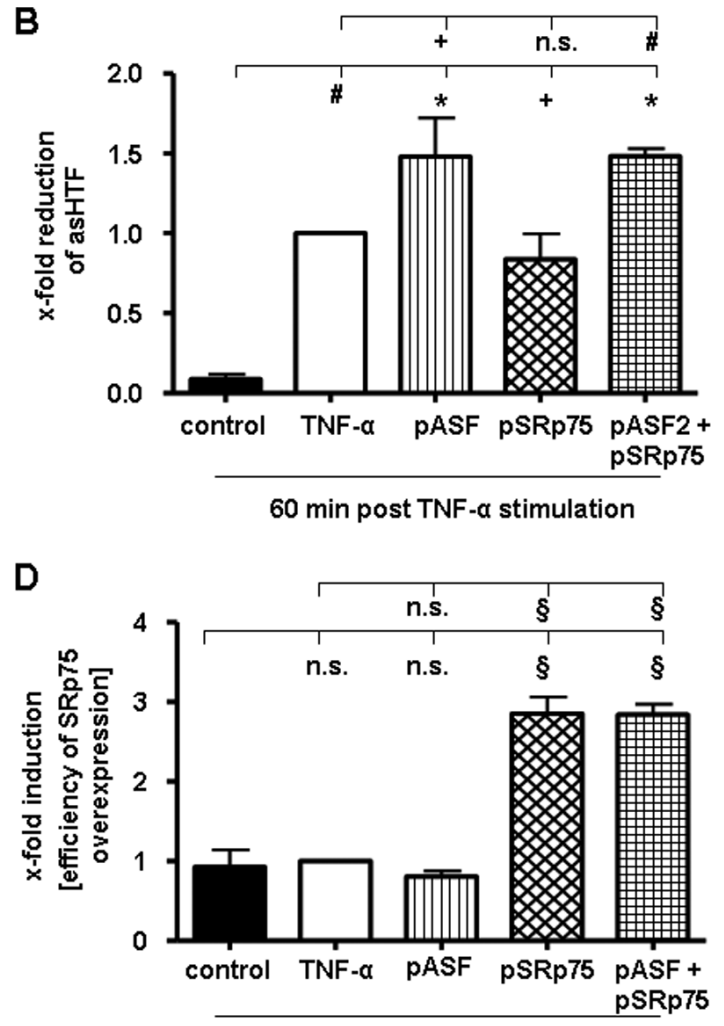

$48 \mathrm{~h}$ post transfection

Figure 5. Overexpression of SF2/ASF and SRp75 alters the differential TF mRNA expression. (A,B) Ratio of the flTF (A) and asHTF (B) mRNA expression normalized against GAPDH of $5 \times 10^{5}$ HUVECs $72 \mathrm{~h}$ post transfection with overexpression plasmids for SF2/ASF and SRp75, and $60 \mathrm{~min}$ post TNF- $\alpha$ stimulation. Shown are unstimulated cells (control), TNF- $\alpha$-stimulated HUVECs (TNF- $\alpha$ ) and cells transfected with $3 \mu \mathrm{g}$ of the overexpression plasmid for SF2/ASF (pASF) and/or SRp75 (pSRp75). (C) Efficiency of SR protein overexpression $48 \mathrm{~h}$ post transfection. In A-C the mean \pm SEM of at least 3 independent experiments is shown. $+\mathrm{P}<0.05 ; * \mathrm{P}<0.01 ; \$ \mathrm{P}<0.001 ; \# \mathrm{P}<0.0001$ compared with unstimulated controls or TNF- $\alpha$-treated cells. See Figures 1,2,4 and text for abbreviations.

activity in alternative splicing processes. ${ }^{17,20}$ To determine the involvement of the SR proteins mentioned before in the differential TF isoform expression, we exemplarily analyzed the impact of SF2/ASF and SRp75 overexpression on the mRNA expression of fITF and asHTF in HUVECs. As mentioned before, stimulation of HUVECs with TNF- $\alpha$ increased the mRNA expression of both TF isoforms $60 \mathrm{~min}$ post stimulation (Figures 5A,B). Overexpression of SF2/ ASF reduced the mRNA expression of flTF and increased that of asHTF. Overexpression of SRp75 led to reduced flTF expression and had no significant impact on asHTF 60 min post induction with TNF- $\alpha$. Simultaneous overexpression of both SR proteins in HUVECs also reduced flTF mRNA, but increased asHTF expression. The SF2/ASF expression was approximately 2.5-fold increased (Figure 5C) and SRp75 was approximately 3-fold increased $48 \mathrm{~h}$ post transfection compared with non-transfected HUVECs (Figure 5D).

\section{Discussion}

SR protein kinases, such as Akt, control the phosphorylation state and activity of SR proteins, thereby regulating alternative splicing. ${ }^{18,19,22,29}$ Our findings demonstrate that the PI3K/Akt pathway is involved in the regulation of the differential TF isoform expression in ECs. We demonstrated the regulatory level of the PI3K/Akt pathway to be distinct from the transcriptional regulation level of $\mathrm{NF} \kappa \mathrm{B} .{ }^{30-33}$ Inhibition of the PI3K/Akt pathway by the pharmacologic inhibitor, LY294002, reduced the TNF$\alpha$-induced mRNA expression of asHTF, but not flTF, in a time- and concentration-dependent manner. In contrast, the inhibition of the transcription factor $\mathrm{NF}_{\kappa} \mathrm{B}$ diminished the expression of both TF isoforms post stimulation with the pro-inflammatory cytokine TNF- $\alpha$. Moreover, we found that $\mathrm{TNF}-\alpha$-induced procoagulant activity was not reduced when levels of asHTF mRNA, but not those of flTF, were lowered by inhibition of the PI3K/Akt pathway. In contrast, $\mathrm{NF}_{\kappa} \mathrm{B}$ inhibition reduced the expression of both TF isoforms, associated with decreased TF activity. This indicates that, compared with flTF, asHTF is likely to be a minor contributor to TNF- $\alpha$-induced increase in endothelial thrombogenicity. 6,34,35 $\mathrm{Yu}$ and Rak found that flTF-containing microparticles, rather than asHTF, were the main source of TF activity released from human cancer cells, ${ }^{13}$ although in the plasma of healthy individuals, non-microparticle associated $\mathrm{TF}$ was shown to be a major source of plasma TF activity. ${ }^{12} \mathrm{We}$ recently showed that soluble TF is much less procoagulant than microparticle-associated full-length TF released from TNF- $\alpha$-stimulated HUVECs. ${ }^{6}$ Despite its minor role in thrombogenicity, asHTF was assumed to be involved in other cellular processes such as angiogenesis and cell proliferation. ${ }^{15}$

Furthermore, we demonstrated in the present study that 
the inhibition of the PI3K/Akt pathway, but not the $\mathrm{NF}_{\kappa} \mathrm{B}$ pathway, led to reduced phosphorylation of the SR proteins, SRp75, SRp55 and SF2/ASF, without affecting the expression of these SR proteins 5 min post TNF- $\alpha$ stimulation. In association with these results, we found overexpression of SF2/ASF and SRp75 alone or in combination influenced the mRNA expression pattern of the TF isoforms in TNF- $\alpha$-induced HUVECs in differing modalities. It has been shown by other groups that the phosphorylation state of SR proteins determines their activity in alternative splicing processes, ${ }^{17,20,36}$ and the activity of distinct SR proteins determines the expression of different isoforms, as shown for TF and other proteins. ${ }^{10,17,18,36,37}$ Blaustein et al showed Akt to be an SR protein kinase that is involved in regulation of the phosphorylation and the activity of SR proteins such as SF2/ASF and 9G8. ${ }^{22}$ Recently, Jiang et al found Akt to regulate induced alternative splicing of protein kinase $\mathrm{C} \beta$ III-pre-mRNA through the phosphorylation of SR proteins. ${ }^{18}$ Other groups have demonstrated that the PI3K/ Akt pathway phosphorylates the SR protein SRp40, thereby regulating alternative splicing processes such as splicing of protein kinase $\mathrm{C} \beta \mathrm{II} .{ }^{23,24}$ Finally, Tardos et al reported that exon 5 of the human TF gene contains ESE motifs for SR proteins, such as SF2/ASF and SRp55. ${ }^{36}$ The binding of SR proteins to these motifs was shown to be essential for the differential TF isoform expression in human monocytic cells. ${ }^{14}$

Altogether, the results of the present study point to the PI3K/Akt pathway being, at least in part, involved in the differential TF isoform expression at the mRNA level by regulation of alternative splicing processes, possibly mediated through the phosphorylation state and activity of the SR proteins SRp75, SRp55 and SF2/ASF in TNF- $\alpha$-induced human ECs. Our results provide new insights into the regulatory network of alternative splicing, especially with respect to the differential TF isoform expression in human ECs. These isoforms are essential for vascular wall homeostasis and blood thrombogenicity. Understanding the regulation of TF mRNA splicing processes may help to develop new strategies for the modulation of vascular wall thrombogenicity.

\section{Acknowledgments}

This work was supported by grants from the Deutsche Forschungsgemeinschaft (DFG) (GRK 865 to U.R. and W.P; SFB-TR19 to U.R. W.P. and H-P.S.).

\section{References}

1. Giesen PL, Rauch U, Bohrman B, Kling D, Roque, Fallon JT, et al. Blood-borne tissue factor: Another view of thrombosis. Proc Natl Acad Sci USA 1999; 96: 2311-2315.

2. Szotowski B, Antoniak S, Rauch U. Alternatively spliced tissue factor: A previously unknown piece in the puzzle of hemostasis. Trends Cardiovasc Med 2006; 16: 177-182.

3. Rauch U, Bonderman D, Bohrmann B, Badimon JJ, Himber J, Riederer MA, et al. Transfer of tissue factor from leukocytes to platelets is mediated by CD15 and tissue factor. Blood 2000; 96: $170-175$.

4. Mackman N. Role of tissue factor in hemostasis, thrombosis, and vascular development. Arterioscler Thromb Vasc Biol 2004; 24: $1015-1022$

5. Rauch U, Nemerson Y. Circulating tissue factor and thrombosis. Curr Opin Hematol 2000; 7: 273-277.

6. Szotowski B, Antoniak S, Poller W, Schultheiss HP, Rauch U. Procoagulant soluble tissue factor is released from endothelial cells in response to inflammatory cytokines. Circ Res 2005; 96: 1233-1239.

7. Morel O, Toti F, Hugel B, Bakouboula B, Camoin-Jau L, DignatGeorge F, et al. Procoagulant microparticles: Disrupting the vascular homeostasis equation? Arterioscler Thromb Vasc Biol 2006; 26: 2594-2604

8. Bobbert P, Antoniak S, Schultheiss HP, Rauch U. Globular adiponectin but not full-length adiponectin induces increased procoagulability in human endothelial cells. J Mol Cell Cardiol 2008; 44: 388-394.

9. Kasuya N, Kishi Y, Isobe M, Yoshida M, Numano F. P-selectin expression, but not GPIIb/III activation, is enhanced in the inflammatory stage of Takayasu's arteritis. Circ J 2006; 70: 600-604.

10. Eisenreich A, Bogdanov VY, Zakrzewicz A, Pries A, Antoniak S, Poller W, et al. Cdc2-like kinases and DNA topoisomerase I regulate alternative splicing of tissue factor in human endothelial cells. Circ Res 2009; 104: 589-599.

11. Szotowski B, Antoniak S, Goldin-Lang P, Tran QV, Pels K, Rosenthal $\mathrm{P}$, et al. Antioxidative treatment inhibits the release of thrombogenic tissue factor from irradiation- and cytokine-induced endothelial cells. Cardiovasc Res 2007; 73: 806-812.

12. Bogdanov VY, Balasubramanian V, Hathcock J, Vele O, Lieb M, Nemerson Y. Alternatively spliced human tissue factor: A circulating, soluble, thrombogenic protein. Nat Med 2003; 9: 458-462.

13. Yu JL, Rak JW. Shedding of tissue factor (TF)-containing microparticles rather than alternatively spliced $\mathrm{TF}$ is the main source of $\mathrm{TF}$ activity released from human cancer cells. J Thromb Haemost 2004; 2: 2065-2067.

14. Bogdanov VY. Blood coagulation and alternative pre-mRNA splicing: An overview. Curr Mol Med 2006; 6: 859-869.

15. Hobbs JE, Zakarija A, Cundiff DL, Doll JA, Hymen E, Cornwell M, et al. Alternatively spliced human tissue factor promotes tumor growth and angiogenesis in a pancreatic cancer tumor model. Thromb Res 2007; 120(Suppl 2): S13-S21.

16. Black DL. Mechanisms of alternative pre-messenger RNA splicing. Annu Rev Biochem 2003; 72: 291-336.

17. Bourgeois CF, Lejeune F, Stévenin J. Broad specificity of SR (serine/ arginine) proteins in the regulation of alternative splicing of pre-messenger RNA. Prog Nucleic Acids Res Mol Biol 2004; 78: 37-88.

18. Jiang K, Patel NA, Watson JE, Apostolatos H, Kleiman E, Hanson O, et al. Akt2 regulation of Cdc2-like kinases (Clk/Sty), serine/argininerich (SR) protein phosphorylation, and insulin-induced alternative splicing of PKCssII mRNA. Endocrinology 2009; 150: 2087-2097.

19. Stamm S. Regulation of alternative splicing by reversible protein phosphorylation. J Biol Chem 2008; 283: 1223-1227.

20. Prasad J, Colwill K, Pawson T, Manley JL. The protein kinase Clk/Sty directly modulates SR protein activity: Both hyper- and hypophosphorylation inhibit splicing. Mol Cell Biol 1999; 19: 6991-7000.

21. Huang CJ, Tang Z, Lin RJ, Tucker PW. Phosphorylation by SR kinases regulates the binding of PTB-associated splicing factor (PSF) to the pre-mRNA polypyrimidine tract. FEBS Lett 2007; 581: 223 232.

22. Blaustein M, Pelisch F, Tanos T, Muñoz MJ, Wengier D, Quadrana L. Concerted regulation of nuclear and cytoplasmic activities of SR proteins by AKT. Nat Struct Mol Biol 2005; 12: 1037-1044.

23. Liu X, Mayeda A, Tao M, Zheng ZM. Exonic splicing enhancerdependent selection of the bovine papillomavirus type 1 nucleotide 3225 3' splice site can be rescued in a cell lacking splicing factor ASF/SF2 through activation of the phosphatidylinositol 3-kinase/Akt pathway. J Virol 2003; 77: 2105-2115.

24. Patel NA, Kaneko S, Apostolatos HS, Bae SS, Watson JE, Davidowitz $\mathrm{K}$. Molecular and genetic studies imply Akt-mediated signaling promotes protein kinase CbetaII alternative splicing via phosphorylation of serine/arginine-rich splicing factor SRp40. J Biol Chem 2005; 280: $14302-14309$.

25. Szotowski B, Goldin-Lang P, Antoniak S, Bogdanov VY, Pathirana D, Pauschinger M. Alterations in myocardial tissue factor expression and cellular localization in dilated cardiomyopathy. $J$ Am Coll Cardiol 2005; 45: $1081-1089$.

26. Eisenreich A, Celebi Ö, Goldin-Lang P, Schultheiss HP, Rauch U. Upregulation of tissue factor expression and thrombogenic activity in human aortic smooth muscle cells by irradiation, rapamycin and paclitaxel. Int Immunopharmacol 2008; 8: 307-311.

27. Seimi SK, Seinosuke K, Tsuyoshi S, Tomomi U, Tetsuaki H, Miki K, et al. Glycogen synthase kinase- $3 \beta$ is involved in the process of myocardial hypertrophy stimulated by insulin-like growth factor-1. Circ J 2004; 68: 247-253.

28. Radhakrishnan G, Suzuki R, Maeda H, Yamamoto M, Hirose N, Gopalrao RK, et al. Inhibition of neointimal hyperplasia development by MCI-186 is correlated with downregulation of nuclear factor $-\kappa \mathrm{B}$ pathway. Circ J 2008; 72: 800-806.

29. Eisenreich A, Boltzen U, Poller W, Schultheiss HP, Rauch U. Effects of the Cdc2-like kinase-family and DNA topoisomerase I on the alternative splicing of eNOS in TNF- $\alpha$-stimulated human endothelial cells. Biol Chem 2008; 389: 1333-1338. 
30. Matsumoto R, Yoshiyama M, Omura T, Kim S, Nakamura Y, Izumi $\mathrm{Y}$, et al. Effects of aldosterone receptor antagonist and angiotensin II type I receptor blocker on cardiac transcriptional factors and mRNA expression in rats with myocardial infarction. Circ J 2004; 68: 376 382.

31. Wang L, Wei W, Hu Y, Song S, Yan Z. An oligonucleotide decoy for nuclear factor-kappa B inhibits tumor necrosis factor-alpha-induced human umbilical cord vein endothelial cell tissue factor expression in vitro. Blood Coagul Fibrinolysis 2004; 15: 483-490.

32. Goldin-Lang P, Pels K, Tran QV, Szotowski B, Wittchen F, Antoniak $\mathrm{S}$, et al. Effect of ionizing radiation on cellular procoagulability and co-ordinated gene alterations. Haematologica 2007; 92: 1091 - 1098

33. Walsh K. Adipokines, myokines and cardiovascular disease. Circ J 2009; 73: $13-18$
34. Goldin-Lang P, Tran QV, Fichtner I, Eisenreich A, Antoniak S, Schulze K, et al. Tissue factor expression pattern in human non-small cell lung cancer tissues indicate increased blood thrombogenicity and tumor metastasis. Oncol Rep 2008; 20: 123-128.

35. Niwa Y, Iwai N. Nanomaterials induce oxidized low-density lipoprotein cellular uptake in macrophages and platelet aggregation. Circ J 2007; 71: 437-444.

36. Tardos JG, Eisenreich A, Deikus G, Bechhofer DH, Chandradas S, Zafar U, et al. SR proteins ASF/SF2 and SRp55 participate in tissue factor biosynthesis in human monocytic cells. J Thromb Haemost 2008; 6: 877-884.

37. Satoh E, Ono K, Xu F, Iijima T. Cloning and functional expression of a novel splice variant of rat TRPC4. Circ J 2002; 66: 954-958. 